\title{
IRRIGATION WITH DOMESTIC TREATED SEWAGE AND NITROGEN FERTILIZING IN SUNFLOWER CULTIVATION
}

\author{
FRANCISCO M. L. BEZERRA ${ }^{1}$, CLEY A. S. DE FREITAS ${ }^{2}$, ALEXANDRE R. A. DA \\ SILVA $^{3}$, SUETÔNIO DE B. MOTA ${ }^{4}$, BOANERGES F. DE AQUINO ${ }^{5}$
}

\begin{abstract}
The objective of this study was to evaluate the productive performance of sunflower plants irrigated with different levels of domestic treated sewage and groundwater well with different doses of nitrogen. It was used randomized blocks design in split-split plots with four replications. In the plots, we evaluated the effect of two types of irrigation water, in the subplots we evaluated the five irrigation levels expressed as 25, 50, 75, 100 and 125\% of the Class A pan Evaporation (CAE), and in the sub subplots, we evaluated the effect of four different doses of nitrogen $(25,50,75$ and $100 \mathrm{~kg} \mathrm{ha}^{-1}$ ). The irrigation of sunflower with domestic sewage produced greater yield potential of grain and oil. The use of water from treated wastewater can replace up to $50 \mathrm{~kg} \mathrm{~N} \mathrm{ha}^{-1}$ without affecting productivity. It is recommended for the commercial production of sunflower the use of treated sewage water with irrigation depth relative to $100 \%$ of CAE (296.64 mm) and nitrogen of 25 $\mathrm{kg} \mathrm{ha}^{-1}$.
\end{abstract}

KEYWORDS: Helianthus annuus, recycle, drip irrigation, nitrogen fertilization.

\section{IRRIGAÇÃO COM ESGOTO DOMÉSTICO TRATADO E DOSES DE NITROGÊNIO NA PRODUÇÃO DO GIRASSOL}

RESUMO: Objetivou-se, com este trabalho, avaliar o desempenho produtivo do girassol irrigado com diferentes lâminas de esgoto doméstico tratado e de água de poço freático, e diferentes doses de nitrogênio. Utilizou-se do delineamento estatístico de blocos ao acaso, no esquema de parcelas subsubdivididas, com quatro repetições. Nas parcelas, avaliou-se o efeito dos dois tipos de água de irrigação; nas subparcelas, as cinco lâminas de irrigação baseadas em percentuais da evaporação do tanque classe A (ECA), que corresponderam à multiplicação da ECA pelos fatores 0,$25 ; 0,50 ; 0,75$; 1,00 e 1,25; e nas subsubparcelas, o efeito das quatro doses de adubação nitrogenada (25; 50; 75 e $100 \mathrm{~kg} \mathrm{ha}^{-1}$ ). A irrigação do girassol com esgoto doméstico promoveu maiores potenciais produtivos de grãos e de óleo. O uso da água proveniente de esgotos domésticos tratados pode substituir até $50 \mathrm{~kg}$ de $\mathrm{N} \mathrm{ha}^{-1}$, sem afetar a produtividade. Recomenda-se, para a produção comercial do girassol, o uso do esgoto doméstico tratado com a lâmina de irrigação referente a 100 \% da ECA (296,64 mm) e adubação nitrogenada de $25 \mathrm{~kg} \mathrm{ha}^{-1}$.

PALAVRAS-CHAVE: Helianthus annuus, reúso, gotejamento, adubação nitrogenada.

\footnotetext{
${ }^{1}$ Eng $^{\circ}$. Agrônomo, Prof. Doutor, Departamento de Engenharia Agrícola, Universidade Federal do Ceará - UFC, Campus do PICI, Bloco 804, Caixa Postal 12.168, Fortaleza, Ceará, Brasil, Fone: (85) 3366 - 9758, mbezerra@ufc.br

${ }^{2}$ Eng $^{\circ}$. Agrônomo, Prof. Doutor, Instituto Federal de Educação, Ciência e Tecnologia do Ceará - IFCE, Tianguá, Ceará, Brasil, cleyanderson@ifce.edu.br

${ }^{3}$ Eng $^{\circ}$. Agrônomo, Prof. Mestre, Instituto Federal de Educação, Ciência e Tecnologia do Piauí - IFPI, Uruçuí, Piauí, Brasil, alexandre.reuber@ifpi.edu.br

${ }^{4}$ Eng ${ }^{\circ}$. Civil, Prof. Doutor, Departamento de Engenharia Hidráulica e Ambiental, Universidade Federal do Ceará - UFC, Fortaleza, Ceará, Brasil, suetonio@secrel.com.br

${ }^{5}$ Eng . Agrônomo, Prof. Doutor, Departamento de Ciências do Solo, Universidade Federal do Ceará - UFC, Fortaleza, Ceará, Brasil, nerges222@yahoo.com.br

Recebido pelo Conselho Editorial em: 17-12-2010

Aprovado pelo Conselho Editorial em: 05-9-2014
} 


\section{INTRODUCTION}

The sunflower (Helianthus annuus L.) was in 2009/2010 the $4^{\circ}$ oil seed most produced in the world, accounting for 7.91\% of the total oil (CONAB, 2010a). In 2009/2010 harvest was estimated that Brazil produced 80.6 thousand tons of sunflower, however, the State of Ceará, contributed only with 0.9 thousand tons. The average productivity of sunflower in Northeastern Brazil $\left(640 \mathrm{~kg} \mathrm{ha}^{-1}\right)$ is below the national average (1,136.8 $\mathrm{kg} \mathrm{ha}^{-1}$ ) (CONAB, 2010b), possibly due to the low and irregular natural rainfall predominate in the region. Thus, the use of irrigation becomes critical to minimize and correct problems stemming from inadequate water supply that routinely has been an impediment to agriculture (GARCIA et. al., 2007).

Numerous assays involving the sunflower crop show that the high productivity of the culture are associated with irrigation handled appropriately. Silva et al. (2007) submitted the sunflower crop to different irrigation depth, in Lavras, MG, and observed significant effects on productive variables. The better result of productive potential $\left(2,863.12 \mathrm{~kg} \mathrm{ha}^{-1}\right)$ and oil yield $\left(675.57 \mathrm{~kg} \mathrm{ha}^{-1}\right)$ was obtained with water irrigation depth of $522.14 \mathrm{~mm}$ (130\% ETc). SILVA et. al. (2011) in Pentecoste, CE, ascertained that the highest yields of sunflower in terms of mass of a thousand achenes, potential production and oil productivity of $71.49 \mathrm{~g}, 3,948.02 \mathrm{~kg} \mathrm{ha}^{-1}$ and $1,760.63 \mathrm{~kg} \mathrm{ha}^{-1}$ were obtained with the water irrigation depth equivalent to $533.7 \mathrm{~mm}$ (150\% CAE), respectively.

Nitrogen fertilization as water is essential for proper development of the sunflower. For SANZONOWICZ \& AMABILE (2001) deficiency of $\mathrm{N}$ in the culture affects the growth and development of plants, the size of the achenes, protein and oil content in seeds and their application can result in an excessive plant lodging and the onset of disease.

BISCARO et. al. (2008) observed that better results for the 1,000 achenes mass (7.19 g) and yield potential $\left(2,101 \mathrm{~kg} \mathrm{ha}^{-1}\right)$ of sunflower were with equivalent dose of $55 \mathrm{~kg} \mathrm{ha}^{-1}$ of nitrogen. With these results it is recommended the application of this nitrogen dose in order to obtain the maximum technique efficiency. However, there is no consensus in the literature regarding to the optimal dose of nitrogen to be applied, capable of maximizing crop production.

In several surveys increments of yield components were observed with increasing of production factors, water irrigation depth and nitrogen levels until reaching a maximum point where the increase of one or two factors promote decreases in production variables. BARROS; COSTA \& AGUIAR (2002) cultivating melons under different water irrigation depth and nitrogen found quadratic behavior of the productive potential due to the studied production factors. SILVA et. al. (2008) found a quadratic adjustment in the productive potential of lettuce with the elevation of production factors water and nitrogen.

Excessive use of water and nutrients in agricultural production are tested, as due to increased production costs and can make production economically unfeasible; as to the environment, due to the possibility of groundwater contamination by fertilizers, as to the excessive water use in agricultural production. In this regard, research into the possible use of treated wastewater for irrigation purposes are being directed in order to have an increasingly sustainable agriculture (RAMOS, 2007).

Given the above, the objective of this study was to evaluate the performance of irrigated sunflower with two types of water (groundwater well and treated sewage) applied to five water irrigation depth and subjected to increasing levels of nitrogen.

\section{MATERIALS AND METHODS}

The experiment was conducted from November to February 2009/2010 in the Research Center for Treatment and Reuse of Wastewater, belonging to the Water and Sewerage Company of Ceará (CAGECE), located in Aquiraz, CE, with coordinates of $3^{\circ} 54$ '05" South latitude and 38 $23^{\circ} 28^{\prime \prime}$ West longitude of Greenwich, at an elevation of approximately 14.2 meters. The climate according to the Köppen climate classification corresponds to AW '(rainy Tropical). The soil of the area 
belongs to the class of Argisoils medium sand texture. Physico-chemical and hydric properties of the soil are shown in Tables 1 and 2 respectively.

TABLE 1. Physical and hydraulic properties of the field soil.

\begin{tabular}{|c|c|c|c|c|c|c|c|c|}
\hline \multirow{2}{*}{ Layer } & \multicolumn{3}{|c|}{ Granulometric composition } & \multirow{2}{*}{ Textural class } & \multicolumn{2}{|c|}{ Density } & \multicolumn{2}{|c|}{ Humidity } \\
\hline & Sand & Silt & Clay & & Soil & Particles & $33 \mathrm{Kpa}$ & $1,500 \mathrm{Kpa}$ \\
\hline (m) & & $\mathrm{g} \mathrm{kg}$ & & $(-)$ & & $\left.\mathrm{dm}^{-3}\right)$ & & $\left.3 \mathrm{~m}^{-3}\right)$ \\
\hline $0.00-0.20$ & 929 & 57 & 14 & Sand & 1.57 & 2.62 & 3.06 & 1.60 \\
\hline $0.20-0.40$ & 925 & 56 & 19 & Sand & 1.58 & 2.62 & 3.17 & 1.48 \\
\hline
\end{tabular}

TABLE 2. Chemical properties of the field soil ${ }^{1}$.

\begin{tabular}{|c|c|c|c|c|c|c|c|c|}
\hline \multirow{2}{*}{ Layer } & \multirow{2}{*}{$\begin{array}{c}\mathrm{pH} \\
\text { (Water) }\end{array}$} & \multirow{2}{*}{$\mathrm{EC}$} & \multicolumn{6}{|c|}{ Exchangeable cations } \\
\hline & & & $\mathrm{Ca}^{2+}$ & $\mathrm{Mg}^{2+}$ & $\mathrm{K}^{+}$ & $\mathrm{Na}^{+}$ & $\mathrm{H}^{+}+\mathrm{Al}^{3+}$ & $\mathrm{Al}^{3+}$ \\
\hline (m) & $(-)$ & $\left(\mathrm{dS} \mathrm{m}^{-1}\right)$ & \multicolumn{6}{|c|}{$\left(\mathrm{cmol}_{\mathrm{c}} \mathrm{kg}^{-1}\right)$} \\
\hline $0.00-0.20$ & 6.0 & 0.13 & 1.4 & 1.3 & 0.09 & 3 & 1.32 & 0.15 \\
\hline $0.20-0.40$ & 5.5 & 0.12 & 1.4 & 1.4 & 0.14 & 6 & 1.48 & 0.15 \\
\hline Layer & $\mathrm{S}$ & $\mathrm{T}$ & $\mathrm{V}$ & PES & O. M. & $\mathrm{P}_{\text {Assimilable }}$ & & \\
\hline$(\mathrm{m})$ & \multicolumn{2}{|c|}{$\left(\mathrm{cmol}_{\mathrm{c}} \mathrm{kg}^{-1}\right)$} & \multicolumn{2}{|c|}{$(\%)$} & $\left(\mathrm{g} \mathrm{kg}^{-1}\right)$ & $\left(\mathrm{mg} \mathrm{kg}^{-1}\right)$ & & \\
\hline $0.00-0.20$ & 5.79 & 7.11 & 81.43 & 1 & 8.69 & 74 & & \\
\hline $0.0-0.40$ & 8.94 & 10.42 & 85.80 & 1 & 6.41 & 30 & & \\
\hline
\end{tabular}

${ }_{\mathrm{T}}^{\mathrm{pH}}$ - hydrogenionic potential, EC - electrical conductivity of the soil saturation extract; $\mathrm{S}$ - sum of bases; $\mathrm{T}$ - the cation exchange capacity; V - base saturation; PES - percentage of exchangeable sodium; O.M. - Organic matter.

The experimental design was randomized blocks with sub-split plots, two treatments in the plot; five in the subplot and four in the sub-subplot with four replicates (Figure 1). The plots consisted of two types of irrigation water (water from groundwater well - GW and domestic treated sewage - DTS). In the subplots were evaluated the effect of five water irrigation depths based on Class "A" tank evaporation (CAE), and in the subsubplots were tested five doses of nitrogen fertilization. In each block with an area of $216 \mathrm{~m}^{2}(6 \mathrm{x} 36 \mathrm{~m})$ were randomly distributed in two plots with an area of $108 \mathrm{~m}^{2}(6 \times 18 \mathrm{~m})$. Within the plots were randomly distributed in subplots consisting of four rows of plants of $6.00 \mathrm{~m}$ in length where two outer lines were considered borders in order to avoid possible influences between the treatments and the two inner rows, useful lines. The plots were randomly assigned in subplots contained approximately 30 plants and were distributed in four rows of $1.50 \mathrm{~m}$, following a regular spacing of $0.20 \times 0.90 \mathrm{~m}$ comprising a population of approximately 55,555 plants ha ${ }^{-1}$. 

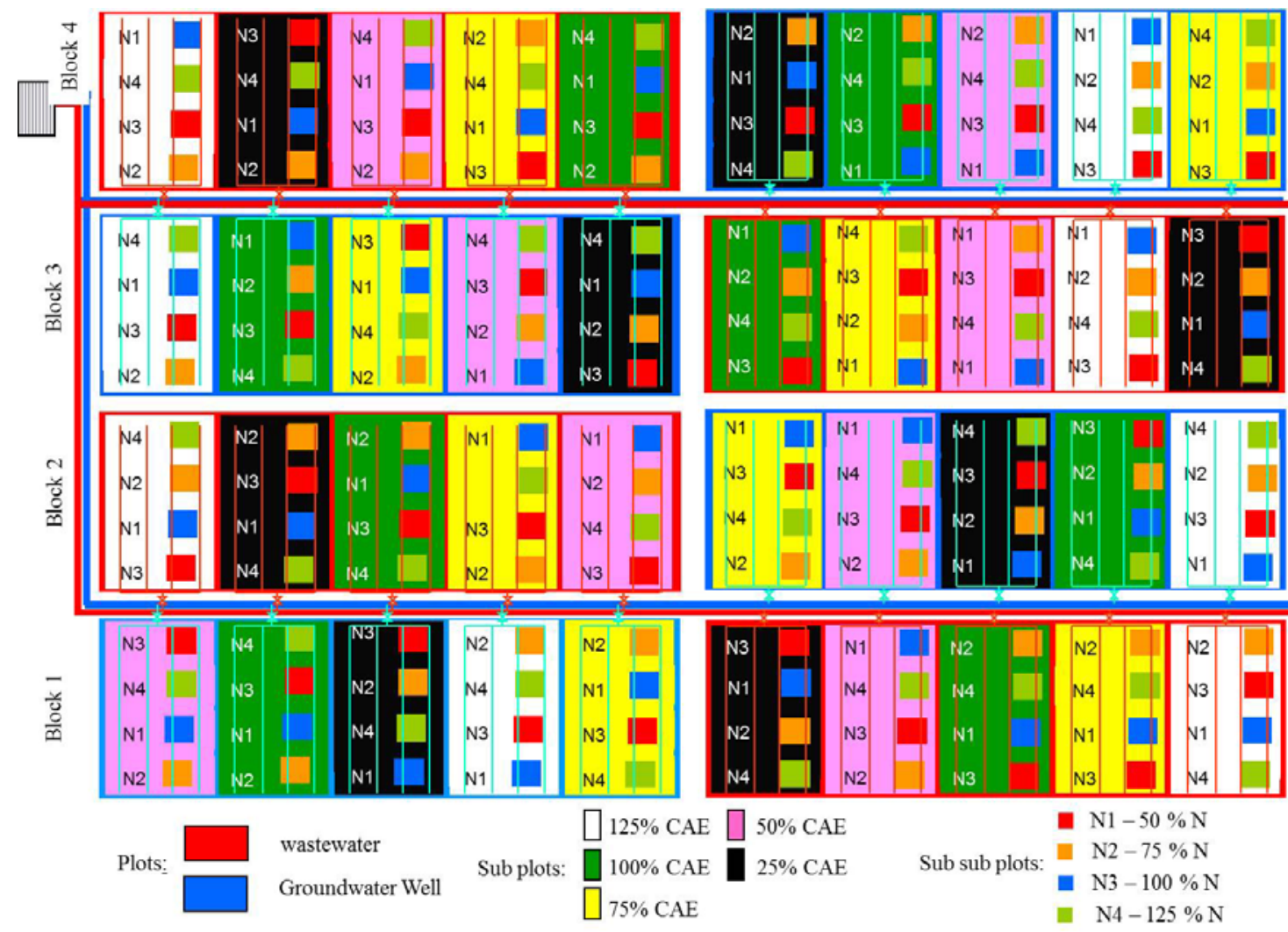

FIGURE 1. General sketch of the experimental area, showing the distribution of treatments in the field schema.

The water irrigation depth based on: L1, irrigation depth based on 25\% of CAE; L2, irrigation depth based on 50\% of CAE; L3 irrigation depth based on 75\% of CAE; L4 irrigation depth based on $100 \%$ of CAE and L5 irrigation depth based on $125 \%$.

Nitrogen rate corresponded to: N1, $25 \mathrm{~kg}$ of $\mathrm{N} \mathrm{ha}^{-1}$; N2, $50 \mathrm{~kg}$ of $\mathrm{N} \mathrm{ha}^{-1}$; N3, $75 \mathrm{~kg}$ of $\mathrm{N}^{-1}$ and $\mathrm{N} 4,100 \mathrm{~kg}$ of $\mathrm{N} \mathrm{ha}^{-1}$ using as source urea (45\% of $\mathrm{N}$ ). $40 \%$ of each dose was applied 15 days after emergence (DAE) and the remaining 60\% were applied at $30 \mathrm{DAE}$.

The culture used in the experiment was the sunflower (Helianthus annus L.) cultivar Multissol, launched in 2004 by the Coordination of Technical Assistance - CATI.

The irrigation method used was the localized type, being two systems (one for irrigation with treated sewage and the other one with groundwater well irrigation), with self-compensating dripper, model Katif with flow of $3.75 \mathrm{~L} \mathrm{~h}^{-1}$ at service pressure of $100 \mathrm{kPa}$, spaced $0.5 \mathrm{~m}$ on the row.

Irrigation management was done through the Class "A" pan. Climatologically data (evaporation and precipitation) were obtained "in situ" by means of the class "A" pan and pluviometer installed near the experimental area. In the first 15 days after planting, all treatments received the same irrigation depth, aiming to establish uniformity in the booth. Irrigations were performed with fixed irrigation interval for two consecutive days. The irrigation time was determined by the depth to be applied, corresponding to the equivalent depth of $100 \%$ of the CAE. After $15^{\text {th }}$ days after sowing it was given the differentiation for the treatments.

The irrigation time for each treatment was calculated based on evaporation information of the class "A" pan measured in the period between two irrigations, crop spacing, percentage of wetted area, uniformity coefficient of application, emitter flow and water application factor as function of the treatments [eq. (1)]. 


$$
T i=\frac{C A E \cdot S 1 \cdot S 2 \cdot P W A \cdot F t}{C u d \cdot q e}
$$

where,

$\mathrm{Ti}$ - Irrigation time for each treatment on $\mathrm{h}$;

CAE - Class "A" pan Evaporation in mm;

S1 e S2 - Crop Spacings, between plants and between rows of plants in $\mathrm{m}$;

PWA - percentage of wetted area on decimal (adopted value 0.40 );

Ft - Water factor application as a function of the treatment in decimal. The Ft amounts used were 0.25 ; 0.50; 0.75; 1.00 and 1.25 for D1, D2, D3, D4 and D5 treatments respectively;

Cud - coefficient of uniformity of application in decimal. Value found in the evaluation system (0.90),

qe - average flow rate of the emitters in L h-1.

The treated sewage used for irrigation came from houses in Aquiraz, Ceará. The physicochemical analysis of the groundwater well and the sewage were carried out at the Laboratory of Environmental Engineering (LABOSAN) and the results are shown in Table 3. Both the groundwater well as the sewage showed acceptable values of total suspended solids and total dissolved solids in relation to the potential for drippers clogging.

TABLE 3. Physicochemical parameters of groundwater well and sewage ${ }^{1}$.

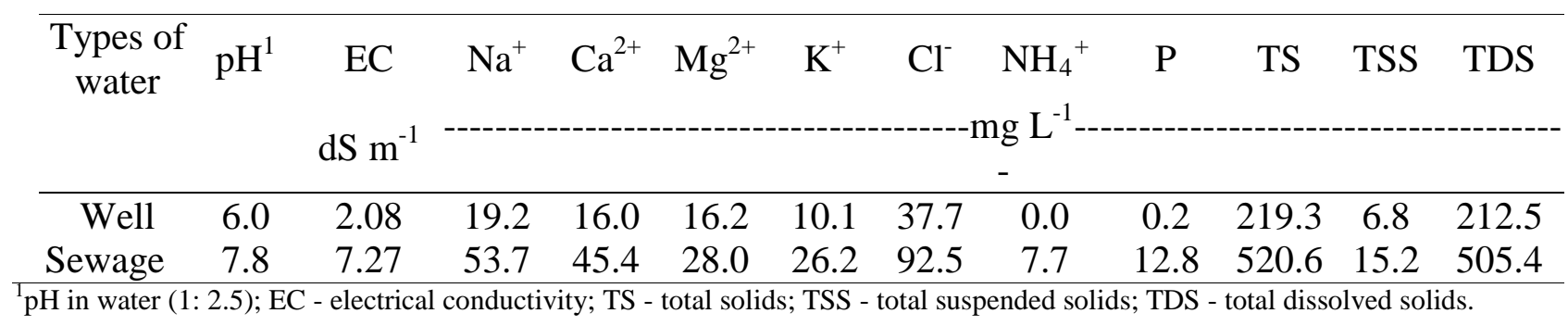

The fertilization of the other nutrients was based on chemical analysis of the soil and nutrient requirements for the crop. It was applied the equivalent of $60 \mathrm{~kg}$ of $\mathrm{P}_{2} \mathrm{O}_{5} \mathrm{ha}^{-1}, 20 \mathrm{~kg}$ of $\mathrm{K}_{2} \mathrm{O} \mathrm{ha}^{-1}$ has been used as the sources of monoammonium phosphate - MAP (48\% of $\mathrm{P}_{2} \mathrm{O}_{5}$ and $9 \%$ of $\mathrm{N}$ ) and potassium sulfate $\left(50 \%\right.$ of $\left.\mathrm{K}_{2} \mathrm{O}\right)$, respectively. The fertilizers were distributed during the vegetative stage of the crop. To compensate possible deficiencies of micronutrients were applied $12 \mathrm{~g}$ of commercial formula FTE BR-12 (9.0\% of $\mathrm{Zn}$; $1.8 \%$ of B; $0.8 \%$ of $\mathrm{Cu}$; $3.0 \%$ of Fe; $2.0 \%$ of $\mathrm{Mn}$ and $0.1 \%$ of Mo) per hole in the foundation as recommended by the Federal University of Ceará (1993). To establish the quantitative dose of $\mathrm{N}$ as urea, it was taken into account the percentage of $\mathrm{N}$ present in the constitution of monoammonium phosphate, being made corrections for all treatments.

Irrigation was ceased at 92 DAE using the criterion of physiological maturity of grains when grains were with hard mass in the phenological stage R9 (chapter inclined downwards, with back and bracts with coloration between yellow and brownish).

At 114 days after sowing (DAS) chapters were collected. The variables evaluated were: mass of 1,000 achenes (M1000A), achene yield potential (PP), oil content (OC) and production potential of oil (PPO).

The mass of a thousand achenes (M1000A) of the experimental units was determined by the direct counting of achenes and by measuring their masses. To do so, an accurate balance was used of four decimal places, and the value was presented in grams. 
The estimated production potential of achenes (PPA) in $\mathrm{kg} \mathrm{ha}^{-1}$ was performed by weighing the production of achenes benefited from plants that were inserted into the working area of the experiment for each experimental unit. The average production of achenes of plants was sampled, calculated and obtained grain yield per plant for each experimental unit. This value was expressed in grams. Subsequently, it was made calculation of the productive potential of achenes expressed in $\mathrm{kg} \mathrm{ha}^{-1}$ for each experimental unit considering the area occupied by each plant and the total number of used plants.

Samples of achenes were taken from each experimental unit to determine oil contents (OC) then were identified, placed in plastic bags and forwarded to the Laboratory of Physiology of the Department of Crop Production from the Ceará Federal University (UFC), Fortaleza, Ceará where the analysis was carried out by calculating the ether extract using the methodology proposed by Silva and Queiroz (2004).

The potential for oil production in $\mathrm{kg} \mathrm{ha}^{-1}$ was estimated for each experimental unit from the product on the values of achenes potential production and the respective oil percentages.

Data were subjected to analysis of variance by $\mathrm{F}$ test at $1 \%$ and $5 \%$ probability. When observed significant effect in the variance analysis, the data obtained in different qualitative treatments were compared by Tukey test and quantitative nature were subjected to regression study.

\section{RESULTS AND DISCUSSION}

The summary of variance analysis for the data of mass for one thousand achenes (M1000A), yield potential (PP), oil content (OC) and production potential of oil (PPO) can be seen in Table 4. By the results presented there was a significant effect of type of water (A) (GW - groundwater well and DTS - domestic treated sewage) in the variables mass of a thousand achenes and productive potential. The different irrigation depths (D) exerted significant effects on all the variables analyzed. In a similar way, increasing nitrogen (N) doses have also played significant effects for all analyzed variable. Interaction A x D was significant for the variables PP and PPO. The interactions between the $\mathrm{A} \times \mathrm{N}$ and $\mathrm{D} \times \mathrm{N}$ was found significant effects for all variables analyzed. In three-way interaction between factors A x D x N, the effects were significant for variables PP and PPO. Significant effects on the interactions reveal the dependence between these evaluated factors.

TABLE 4. Summary of analysis of variance for mass data of a thousand seeds (M1000A), grain yield potential (PP), oil content (OC) and yield potential of oil (PPO) of sunflower under two types of irrigation water (groundwater well and treated sewage), five irrigation depths (D) and four doses of nitrogen $(\mathrm{N})^{1}$.

\begin{tabular}{|c|c|c|c|c|c|}
\hline \multirow{2}{*}{ Sources of variation } & \multirow{2}{*}{ G. L. } & \multicolumn{4}{|c|}{ Mean Squares } \\
\hline & & M1000A & PP & OC & PPO \\
\hline Block & 3 & $12.658^{\mathrm{ns}}$ & $53671.79^{\mathrm{ns}}$ & $51.917^{\mathrm{nS}}$ & $70302.99^{\mathrm{ns}}$ \\
\hline Trat. (A) & 1 & $50.113^{\mathrm{ns}}$ & $1437780.66^{* *}$ & $3.538^{\mathrm{ns}}$ & $127081.5^{\mathrm{ns}}$ \\
\hline Res. A & 3 & 32.179 & 13297 & 51.601 & 35811.18 \\
\hline Trat. (D) & 4 & $516.345^{* *}$ & $7762277.790^{* *}$ & $17.014^{\mathrm{ns}}$ & $1039444.29^{* *}$ \\
\hline Int. A x D & 4 & $120.134^{* *}$ & $1363481.785^{* *}$ & $7.782^{\mathrm{ns}}$ & $119852.80^{* *}$ \\
\hline Res. D & 24 & 14.055 & 18515.13 & 9.367 & 10228.99 \\
\hline Trat. (N) & 3 & $118.296^{* *}$ & $3154281.648^{* *}$ & $14.771^{\mathrm{ns}}$ & $397819.53^{* *}$ \\
\hline Int. $\mathrm{A} \times \mathrm{N}$ & 3 & $70.016^{* *}$ & $1367029.495^{* *}$ & $12.155^{\mathrm{ns}}$ & $217774.5^{* *}$ \\
\hline Int. D x N & 12 & $46.252^{* *}$ & $282445.021^{* *}$ & $5.998^{\mathrm{ns}}$ & $42642.32^{* *}$ \\
\hline Int. $A \times D \times N$ & 12 & $50.182^{* *}$ & $220983.842^{* *}$ & $5.433^{\mathrm{ns}}$ & $42366.39^{* *}$ \\
\hline Res. N & 90 & 12.771 & 26177.59 & 4.912 & $7985.93^{* *}$ \\
\hline
\end{tabular}




\section{Bulk of thousand achenes}

For the variable mass of 1000 achenes $(\mathrm{M} 1000 \mathrm{~A})$ no statistical difference $(\mathrm{p}<0.05)$ was observed as a function of water used in irrigation (Table 4). Corroborating with LUCAS FILHO et al. (2002) who also observed no significant differences between the masses of thousand achenes obtained for sunflower irrigated with groundwater well and treated sewage.

A greater variation in M1000A with changes in water availability was used rather than nitrogen doses (Table 5). The greatest average mass of a thousand achenes (M1000A) on irrigated sunflower with groundwater well were obtained with treatment D4. As for irrigation with sewage M1000A major averages were obtained with depth D3 corroborating with research by SILVA et al. (2011) that also observed significant effects on the M1000A due different irrigation depths.

The larger M1000A were 73.39 and $71.49 \mathrm{~g}$ obtained with irrigation depth of 498.5 (140.10\% CAE) and $533.7 \mathrm{~mm}$ (150\% CAE) for Catissol 01 and Embrapa 122 V-2000 cultivars, respectively according to the authors. These values were higher than those observed in this study, and such differences may be related to genetic differences that are inherent to the cultivars.

TABLE 5. Medium mass of 100 seeds (M1000A) on the basis of two types of irrigation water (A), water depth (D) and levels of irrigation $(\mathrm{N})^{1}$.

\begin{tabular}{|c|c|c|c|c|c|c|c|}
\hline \multirow{3}{*}{ Type of water } & \multirow{2}{*}{\multicolumn{2}{|c|}{ Irrigation depths (mm) }} & \multicolumn{4}{|c|}{ Nitrogen levels $\left(\mathrm{kg} \mathrm{ha}^{-1}\right)$} & \multirow{3}{*}{ Mean } \\
\hline & & & N1 & N2 & N3 & N4 & \\
\hline & & & 25 & 50 & 75 & 100 & \\
\hline \multirow{6}{*}{ Well } & D1 & 74.16 & 51.20 & 53.12 & 56.02 & 55.16 & 53.87 \\
\hline & D2 & 148.32 & 60.24 & 60.64 & 65.43 & 63.43 & 62.43 \\
\hline & D3 & 222.48 & 60.94 & 69.67 & 65.45 & 55.53 & 62.90 \\
\hline & D4 & 296.64 & 55.75 & 66.60 & 69.21 & 64.61 & 64.04 \\
\hline & D5 & 370.80 & 55.64 & 56.72 & 59.32 & 59.57 & 57.81 \\
\hline & Meal & & 56.75 & 61.35 & 63.09 & 59.66 & $60.21 \mathrm{a}$ \\
\hline \multirow{6}{*}{ Sewage } & D1 & 74.16 & 49.55 & 52.06 & 53.75 & 62.24 & 54.40 \\
\hline & D2 & 148.32 & 59.66 & 59.52 & 63.43 & 58.32 & 60.23 \\
\hline & D3 & 222.48 & 71.12 & 62.81 & 64.10 & 69.25 & 66.82 \\
\hline & D4 & 296.64 & 58.35 & 61.50 & 62.98 & 62.12 & 61.24 \\
\hline & D5 & 370.80 & 61.56 & 65.50 & 64.85 & 63.99 & 63.97 \\
\hline & \multicolumn{2}{|c|}{ Mean } & 60.05 & 60.28 & 61.82 & 63.18 & $61.33 \mathrm{a}$ \\
\hline
\end{tabular}

${ }^{1}$ Means followed by the same lower case letter in bold in the column do not differ statistically by the Tukey test at 5\% probability.

The variation of nitrogen fixation with water depth was found that under irrigation with groundwater well the M1000A of treatment N1 (25 kg ha-1) was lower than the mass obtained in other treatments (Table 5). For the irrigated one treated by sewage there was a slight variation of the M1000A due to the variation on nitrogen doses.

The highest average M1000A were obtained by 75 and $100 \mathrm{~kg}$ of $\mathrm{N} \mathrm{ha}^{-1}$ with groundwater well (63.09 g) and sewage water (63.18 g), respectively. These values were lower than those observed by BISCARO et. al. (2008), when subjected the sunflower crop to four doses of nitrogen $\left(0,20,40\right.$ and $\left.80 \mathrm{~kg} \mathrm{ha}^{-1}\right)$ found that the maximum mass of a thousand achenes of approximately $71.9 \mathrm{~g}$ with $44.9 \mathrm{~kg} \mathrm{ha}^{-1}$ of $\mathrm{N}$.

According to regression analysis it was found that the model that better fitted the data, significant by $\mathrm{F}$ test at $1 \%$ probability, is provided on Table 6 . 
TABLE 6. Regression equations and adjusted coefficients of determination $\left(\mathrm{R}^{2}\right)$ for achene mass of one thousand, depending on the blades of irrigation and nitrogen levels.

\begin{tabular}{|c|c|c|c|c|c|c|}
\hline Type of water & Name & Coefficient & Standard deviation & T value & Probab. & $\mathrm{R}^{2}$ \\
\hline \multirow{8}{*}{$\begin{array}{c}\text { Groundwater } \\
\text { Well }\end{array}$} & & & Model & & & \\
\hline & & $\mathrm{Y}=\mathrm{a}+$ & $X+c \overline{X^{2}+d} z+e Z^{2}$ & $\mathrm{fXZ}$ & & \\
\hline & Constant & 31.5633 & & & & \multirow{6}{*}{0.82} \\
\hline & LAM & 0.189437 & 0.0387110 & 4.8936 & 0.0001 & \\
\hline & $\mathrm{LAM}^{2}$ & -0.00039112 & 0.00007834 & -4.9926 & 0.0001 & \\
\hline & NIT & 0.376563 & 0.156353 & 2.4084 & 0.0152 & \\
\hline & $\mathrm{NIT}^{2}$ & -0.002762 & 0.0011534 & -2.3946 & 0.0156 & \\
\hline & NIT*LAM & -0.00001034 & 0.000245925 & -0.04206 & 0.4835 & \\
\hline \multirow{8}{*}{ Treated Sewage } & \multicolumn{6}{|c|}{$Y=a+b X+c X^{2}+d Z+e Z^{2}+f X Z+g X^{2} Z$} \\
\hline & Constant & 29.7013 & & & & \\
\hline & LAM & 0.279388 & 0.102453 & 2.726995 & 0.0086 & \\
\hline & $\mathrm{LAM}^{2}$ & -0.0005264 & 0.00022591 & -2.33038 & 0.0183 & \\
\hline & NIT & 0.228408 & 0.223639 & 1.021323 & 0.1629 & 0.82 \\
\hline & $\mathrm{NIT}^{2}$ & 0.0004536 & 0.00135787 & 0.334053 & 0.3718 & \\
\hline & LAM*NIT & -0.002337 & 0.0014964 & -1.56183 & 0.712 & \\
\hline & $\mathrm{LAM}^{2 *} \mathrm{NIT}$ & 0.00000461 & 0.0000033 & 1.396041 & 0.0930 & \\
\hline
\end{tabular}

Figure 2A represents the response surface of the M1000A estimated as a function of irrigation and nitrogen for sunflower irrigated with groundwater well. The increments of the M1000A were estimated with increase of irrigation depth and nitrogen doses. According to the mathematical model the maximum mass of $66.16 \mathrm{~g}$ was estimated for treatment D3N3 (222.48 mm of water and $66.87 \mathrm{~kg} \mathrm{~N} \mathrm{ha}^{-1}$ ), thereafter the increase in these production factors reduce the weight of a thousand achenes. BISCARO et. al., (2008) also observed quadratic behavior of the mass on sunflower thousand achenes, cultivar H 358 Dekalb due to the increase on nitrogen doses.
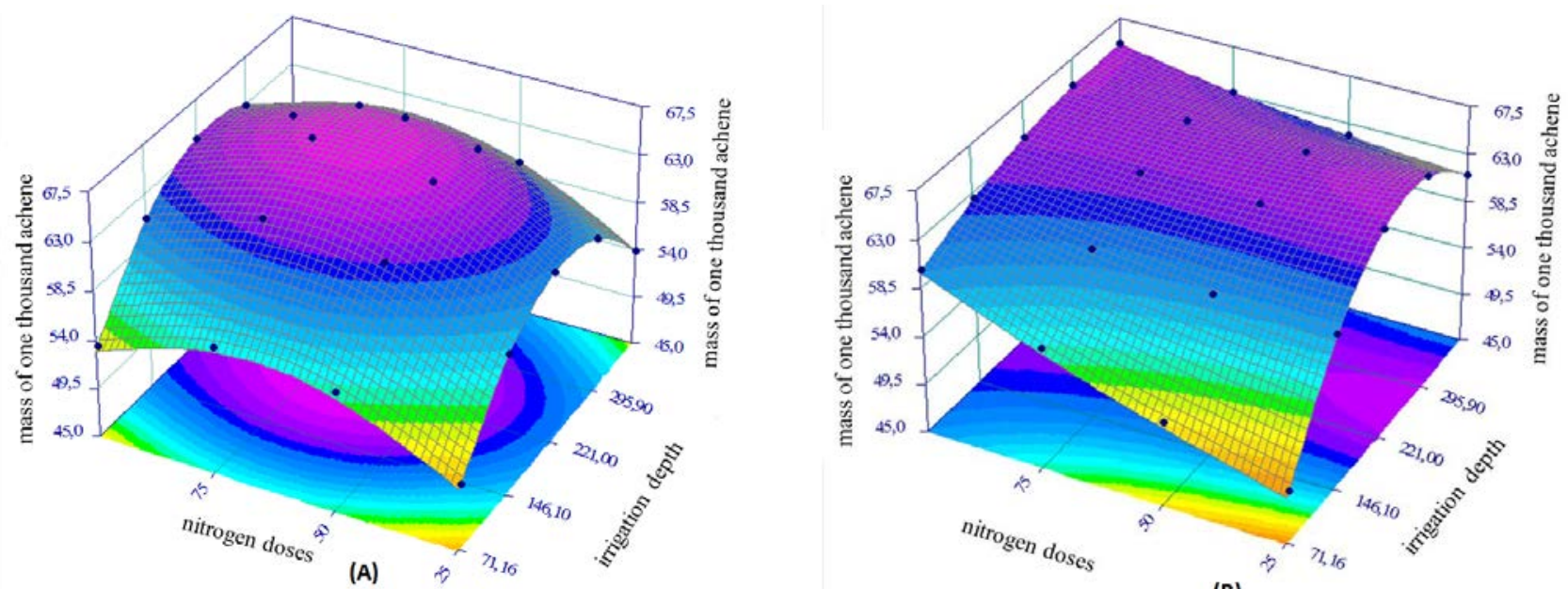

(B)

FIGURE 2. Response surface of the mass of the 1000 seeds sunflower irrigated with groundwater well (A) and with domestic treated sewage (B) as a function of irrigation water and nitrogen doses. 
SILVA et al. (2011) observed an increase in linear and quadratic M1000A for Catissol 01 and Embrapa 122 V - 2000 cultivar, according to different levels of irrigation, respectively. The largest masses of thousand achenes $73.39 \mathrm{~g}$ and $71.49 \mathrm{~g}$ were estimated in 498.5 (140.1\% of CAE) and $533.7 \mathrm{~mm}$ of water (150\% of CAE) for Catissol 01 and Embrapa $122 \mathrm{~V}$ - 2000 cultivars, respectively.

According to the response surface M1000A (Figure 2B), it was found that the sunflower irrigated with the sewage showed an increase weigth of one thousand achenes with increasing on water depth and nitrogen levels. Most M1000A of $65.05 \mathrm{~g}$ was estimated in the treatment D3N1. Already for sunflower irrigated with groundwater well maximum M1000A was estimated for the treatment D3N3.

This proximity from M1000A with their respective treatments reveal a saving of $50 \mathrm{~kg}$ of $\mathrm{N}$ $\mathrm{ha}^{-1}$ for irrigated sunflower with sewage water, the benefit that can probably be explained by the levels of nitrogen present in the sewage.

\section{Grain yield potential}

The highest average grain yield potential (PP) were obtained for domestic treated sewage (2987 kg ha ${ }^{-1}$ ) differing statistically $(\mathrm{p}<0.01)$ than that obtained for groundwater well $\left(2798 \mathrm{~kg} \mathrm{ha}^{-}\right.$ $\left.{ }^{1}\right)$ (Table 7). LUCAS FILHO et. al. (2002) also observed higher PP for irrigated sunflower with reuse water compared to the one irrigated with groundwater well. Similar results were also observed by SOUZA et al. (2010) working with castor observed higher yields for irrigated crop with treated sewage.

TABLE 7. Averages of the productive potential (PP) as a function of two types of irrigation water (A), water depth (D) and levels of irrigation $(\mathrm{N})^{1}$.

\begin{tabular}{|c|c|c|c|c|c|c|c|}
\hline \multirow{3}{*}{ Type of water } & \multirow{3}{*}{\multicolumn{2}{|c|}{ Irrigation depths (mm) }} & \multicolumn{4}{|c|}{ Nitrogen levels $\left(\mathrm{Kg} \mathrm{ha}^{-1}\right)$} & \multirow{3}{*}{ Mean } \\
\hline & & & N1 & N2 & N3 & $\mathrm{N} 4$ & \\
\hline & & & 25 & 50 & 75 & 100 & \\
\hline \multirow{5}{*}{$\begin{array}{l}\text { Groundwater } \\
\text { Well }\end{array}$} & D1 & 74.16 & 1907.40 & 2301.79 & 2675.53 & $1.914,93$ & $2.199,91$ \\
\hline & D2 & 148.32 & 2786.42 & 2909.72 & 3320.48 & $2.817,62$ & $2.958,56$ \\
\hline & D3 & 222.48 & 3070.33 & 3564.88 & 3843.66 & $2.464,02$ & $3.235,72$ \\
\hline & D4 & 296.64 & 2850.58 & 3177.71 & 4130.34 & $3.030,04$ & $3.297,17$ \\
\hline & D5 & 370.80 & 1864.73 & 2270.18 & 2894.58 & $2.159,27$ & $2.297,19$ \\
\hline & Mean & & 2495.89 & 2844.85 & 3372.92 & 2477,17 & 2797.71 b \\
\hline \multirow{5}{*}{ Treated Sewage } & D1 & 74.16 & 1784.12 & 2042.32 & 2122.04 & 2360.03 & 2077.13 \\
\hline & D2 & 148.32 & 2838.47 & 2641.04 & 3238.78 & 2907.61 & 2906.47 \\
\hline & D3 & 222.48 & 3337.14 & 2908.80 & 3410.51 & 3415.79 & 3268.06 \\
\hline & D4 & 296.64 & 3561.34 & 2922.94 & 3849.84 & 3613.57 & 3486.92 \\
\hline & D5 & 370.80 & 2489.30 & 3421.26 & 3488.72 & 3379.17 & 3194.61 \\
\hline
\end{tabular}

${ }^{1}$ Means followed by the same lower case letter in bold in the column do not differ statistically by the Tukey test at 5\% probability.

Values of PP observed in this study are higher than those obtained by AFFÉRRI et al. (2008) of $2427 \mathrm{~kg} \mathrm{ha}^{-1}$ who working with the same cultivar (Multissol) under rainfed conditions in Tocantins, Brazil. This difference in productivity may be associated with the use of irrigation in this study since SILVA et.al. (2011) attributed the good results obtained with sunflower drip irrigated to the possibility of water distribution throughout the crop cycle on agricultural production.

The mean values of PP obtained in study with treated sewage were close, however inferior to the average value obtained by SILVA et. al. (2011) of $3162.98 \mathrm{~kg} \mathrm{ha}^{-1}$ for Embrapa $122 \mathrm{~V}-2000$ also drip irrigated. This difference may be related to genetic differences, since according to 
FARIAS NETO et. al. (2000) variations between genotypes are intrinsic and greatly influenced by environmental conditions and cultural practices adopted by the cultivation of sunflower.

With treatment N3 (75 kg of N ha ${ }^{-1}$ ) were obtained the highest PP 3300 and $3239 \mathrm{~kg} \mathrm{ha}^{-1}$ for groundwater well and sewage, respectively. For groundwater well the average yield potential obtained with the N3 treatment outperformed other treatments. As for the treated sewage, there was less variation in PP as a function of nitrogen levels (Table 7).

There were increases of approximately 35 and 16\% of PP between N3 and N1 treatments, observed for groundwater well and sewage, respectively (Table7). The smallest increment of PP as a function of increased on nitrogen found in sewage water is due to presence in sewage, thus, the dissolved nitrogen in sewage water plus the nitrogen applied in fustigation favored the supply nitrogen nutrition on the crop. For BLANMEY et. al. (1997) the nitrogen is among the nutrients that most limits the sunflower production.

The average yield potential of grain (using treated sewage for irrigation and nitrogen fertilization of $25 \mathrm{~kg} \mathrm{ha}^{-1}$ ) was $2802 \mathrm{~kg} \mathrm{ha}^{-1}$, close to $2845 \mathrm{~kg} \mathrm{ha}^{-1}$ with $50 \mathrm{~kg}$ of N ha ${ }^{-1}$ under groundwater well irrigation, that is, using treated sewage provided a saving of $25 \mathrm{~kg}$ of $\mathrm{N}^{-1}$ which shows a possible partial substitution of the nitrogen on the irrigation with treated sewage water (Table 7).

For the regression analysis, it was found that the model that better fitted the significant data by $\mathrm{F}$ test at the $1 \%$ level of probability, is provided in Table 8 .

TABLE 8. Regression equations and adjusted coefficients of determination $\left(\mathrm{R}^{2}\right)$ to the productive potential, depending on the blades of irrigation and nitrogen levels.

\begin{tabular}{|c|c|c|c|c|c|c|}
\hline Type of water & Name & Coeficiente & Standard deviation & $\mathrm{T}$ value & Probab. & $\mathrm{R}^{2}$ \\
\hline \multirow{8}{*}{$\begin{array}{c}\text { Groundwater } \\
\text { Well }\end{array}$} & \multicolumn{6}{|c|}{ Model } \\
\hline & Constant & -1273.66 & & & & \\
\hline & LAM & 28.2815 & 0.085553 & 3.30572 & 0.0028 & \\
\hline & $\mathrm{LAM}^{2}$ & -0.064377 & 0.018864 & -3.41264 & 0.0023 & \\
\hline & NIT & 70.059 & 0.001867 & 3.75149 & 0.0012 & 0.82 \\
\hline & $\mathrm{NIT}^{2}$ & -0.49788 & 0.111339 & -4.39093 & 0.0004 & \\
\hline & NIT*LAM & -0.095819 & 0.124958 & -0.76681 & 0.2284 & \\
\hline & $\mathrm{NIT}^{*} \mathrm{LAM}^{2}$ & 0.0002543 & 0.000275 & 0.922803 & 0.1865 & \\
\hline \multirow{7}{*}{ Treated Sewage } & \multicolumn{6}{|c|}{$Y=a+b X+c X^{2}+d Z+e Z^{2}+f X Z$} \\
\hline & Constant & 660.813 & & & & \\
\hline & LAM & 16.8652 & 0.03450 & 4.8878 & 0.0001 & \\
\hline & $\mathrm{LAM}^{2}$ & -0.03099 & 0.00698 & -4.4382 & 0.0003 & \\
\hline & NIT & 6.76871 & 0.001394 & 0.4857 & 0.3173 & 0.82 \\
\hline & NIT $^{2}$ & -0.02878 & 0.10281 & -0.2799 & 0.3918 & \\
\hline & LAM*NIT & 0.011529 & 0.021920 & 0.52598 & 0.3036 & \\
\hline
\end{tabular}

According to the response surface (Figure $3 \mathrm{~A}$ ) it can be observed an increase on PP to a maximum of $3538 \mathrm{~kg} \mathrm{ha}^{-1}$ wherein it was estimated the maximum point with the treatment D3N3, since then, the increasing of these production factors provide reduced yield potential.

The estimated productive potential for treatments 50 and $75 \mathrm{~kg}$ of $\mathrm{N} \mathrm{ha}^{-1}$ and irrigation depth equivalent to $222.48 \mathrm{~mm}$ resembled 3653.52 and $3630.80 \mathrm{~kg} \mathrm{ha}^{-1}$, respectively, with difference of about $0,6 \%$. Thus, it is assumed that could be adopted lower dosage (50 kg ha-1 of $\mathrm{N}$ ).

The estimated PP for irrigated sunflower with sewage water due to the increase of irrigation depth and nitrogen level were observed less pronounced and linearly as a function of nitrogen levels 
increase (Figure 3B). As function of irrigation depth this increase was more pronounced and quadratic. According to a mathematical equation, the maximum yield potential estimated would be about $3668.00 \mathrm{~kg} \mathrm{ha}^{-1}$ for irrigation depth of $296.64 \mathrm{~mm}$ and nitrogen dose of $100 \mathrm{~kg} \mathrm{ha}^{-1}$, referring to treatment D4N4, since then presenting decreasing PP due to increasing on water depth.

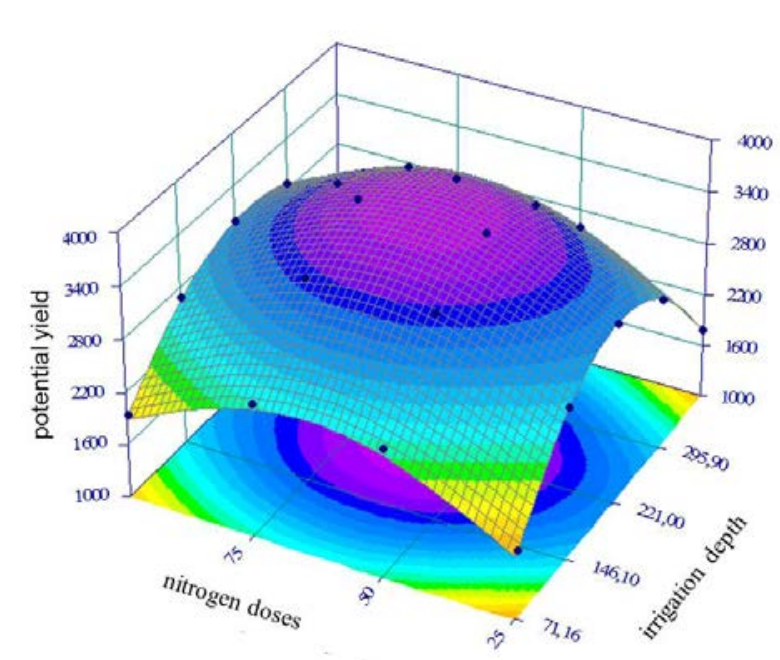

(A)

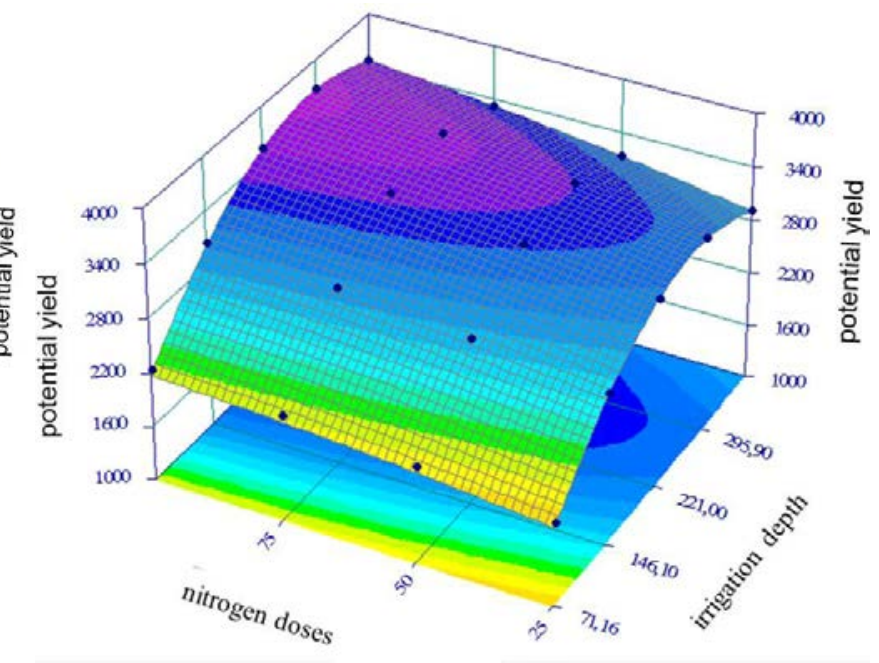

(B)

FIGURE 3. Response surface of the productive potential of sunflower irrigated with groundwater well (A) and with domestic treated sewage (B) as a function of irrigation water and nitrogen doses.

Although it has been estimated that to obtain the maximum PP, sunflower irrigated with domestic treated sewage has spent more water and nitrogen fertilizer (D4N4) compared to irrigation with groundwater well (D3N3) it was found that by setting the irrigation depth of sewage in 296.64 $\mathrm{mm}$ (D4) and reduced nitrogen fertilization from N4 $(100 \mathrm{~kg})$ to N1 (25 kg) there is a reduction of $3667.81 \mathrm{~kg} \mathrm{ha}^{-1}$ to $3173.43 \mathrm{~kg} \mathrm{ha}^{-1}$ that is a decrease of approximately $13 \%$ of PP, but saving $75 \mathrm{~kg}$ $\mathrm{ha}^{-1}$ of $\mathrm{N}$. This difference in PP is due to the nitrogen and other nutrients present in the treated sewage, as previously mentioned. According to CHERNICHARO (2001), the application of nutrients in treated effluent can reduce, or even eliminate, the need for commercial fertilizers.

\section{Oil content}

No significant statistically differences in oil content were observed as a function of production factors studied (Table 4). Corroborating with LOBO \& GRASSI FILHO (2007) working with partial and total substitution of commercial nitrogen by the sludge from sewage did not found significant differences in oil content for sunflower. Also SOUZA et. al. (2010) working with castor bean culture, found no significant effect in oil contents as function of water (well and sewage) and split fertilization.

This no significant difference in oil content, due to the water levels differ from SILVA et. al. (2011). The present study, corroborating with CARVALHO \& PISSAIA (2002) also found no significant effect on oil content as a function of nitrogen rates.

\section{Oil Production Potential}

The average productive potential oil (PPO) of 953.67 and $1010.04 \mathrm{~kg} \mathrm{ha}^{-1}$ obtained with groundwater well and treated sewage water were not statistically different $(p<0.05)$, respectively. These values were higher than those observed by GRUNVALD et. al. (2008) of $731 \mathrm{~kg} \mathrm{ha}^{-1}$ for Multissol. 
The statistical difference of PPO as a function of irrigation depth, found in this study are consistent with SILVA et. al. (2011). For sunflower irrigation with groundwater well, the highest PPO $1087.40 \mathrm{~kg} \mathrm{ha}^{-1}$ was obtained with treatment D3 $(222.48 \mathrm{~mm})$. As for sunflower irrigated with sewage, the highest PPO $1184.15 \mathrm{~kg} \mathrm{ha}^{-1}$ was obtained with treatment D4 (296.64 mm) (Table 9).

TABLE 9. Averages of the productive potential of oil (PPO) as a function of two types of irrigation water (A), water depth (D) and levels of irrigation $(\mathrm{N})^{1}$.

\begin{tabular}{|c|c|c|c|c|c|c|c|}
\hline \multirow{3}{*}{ Type of water } & \multirow{3}{*}{\multicolumn{2}{|c|}{ Irrigation depths (mm) }} & \multicolumn{4}{|c|}{ Nitrogen levels $\left(\mathrm{Kg} \mathrm{ha}^{-1}\right)$} & \multirow{3}{*}{ Mean } \\
\hline & & & N1 & $\mathrm{N} 2$ & N3 & $\mathrm{N} 4$ & \\
\hline & & & 25 & 50 & 75 & 100 & \\
\hline \multirow{5}{*}{$\begin{array}{c}\text { Groundwater } \\
\text { Well }\end{array}$} & D1 & 74.16 & 633.91 & 797.62 & 865.13 & 596.90 & 723.39 \\
\hline & D2 & 148.32 & 981.72 & 997.91 & 1166.97 & 946.58 & 1023.30 \\
\hline & D3 & 222.48 & 1.026 .36 & 1.200 .32 & 1326.61 & 796.31 & 1087.40 \\
\hline & D4 & 296.64 & 948.26 & 1.104 .56 & 1418.50 & 1011.53 & 1120.71 \\
\hline & D5 & 370.80 & 627.95 & 794.42 & 1090.38 & 741.50 & 813.56 \\
\hline & Mean & & 843.64 & 978.97 & 1173.52 & 818.56 & $953.67 \mathrm{a}$ \\
\hline \multirow{6}{*}{ Treated Sewage } & D1 & 74.16 & 598.99 & 660.01 & 681.25 & 733.12 & 668.34 \\
\hline & D2 & 148.32 & 1030.68 & 889.13 & 1129.93 & 922.41 & 993.04 \\
\hline & D3 & 222.48 & 1201.88 & 932.40 & 1223.45 & 1182.34 & 1135.02 \\
\hline & D4 & 296.64 & 1235.46 & 976.58 & 1269.00 & 1255.56 & 1184.15 \\
\hline & D5 & 370.80 & 845.23 & 1210.32 & 1119.03 & 1103.96 & 1069.64 \\
\hline & Mean & & 982.45 & 933.69 & 1084.53 & 1039.48 & $1010.04 \mathrm{a}$ \\
\hline
\end{tabular}

${ }^{1}$ Means followed by the same lower case letter in bold in the column do not differ statistically by the Tukey test at 5\% probability.

For sunflower irrigation with groundwater well there was an increase of approximately $39 \%$ when compared to the PPO obtained in N3 and N1 treatments. As for the treated sewage was recorded $16 \%$ increase when compared to the maximum and minimum averages obtained with N3 and N2 treatments, respectively (Table 9). These smallest increment reinforces the prerogative that the nitrogen presented in domestic sewage can partially replace the commercial nitrogen.

The decrease of PPO observed with N4 might be related to N excess in the plant. According to ZAGONEL \& MUNDSTOCK (1991) high levels of nitrogen can occasionally reduce the oil content in the achenes.

According to regression analysis it was found that the model that better fitted the data, significant by the $\mathrm{F}$ test at the $1 \%$ level of probability is provided in Table 10. 
TABLE 10. Regression equations and adjusted coefficients of determination $\left(\mathrm{R}^{2}\right)$ to the productive potential of oil, depending on the blades of irrigation and nitrogen levels.

\begin{tabular}{|c|c|c|c|c|c|c|}
\hline Type of water & Name & Coefficient & Standard deviation & T value & Probab. & $\mathrm{R}^{2}$ \\
\hline \multirow{8}{*}{$\begin{array}{l}\text { Groundwater } \\
\text { Well }\end{array}$} & & & Model & & & \\
\hline & \\
\hline & Constant & $\frac{\mathrm{Y}=\mathrm{a}+\mathrm{b} * \mathrm{X}+\mathrm{c}^{*} \mathrm{X}^{2}+\mathrm{d}^{*} \mathrm{Z}+\mathrm{e}^{*} \mathrm{Z}^{2}+\mathrm{f}^{*} \mathrm{XZ}}{-259753}$ & & & & \multirow{6}{*}{0,81} \\
\hline & LAM & 6.96193 & 1.37447 & 5.0651 & 0.0001 & \\
\hline & $\mathrm{LAM}^{2}$ & -0.161684 & 0.00278148 & -5.8129 & 0.0000 & \\
\hline & NIT & 22.8306 & 5.55172 & 4.1123 & 0.0005 & \\
\hline & $\mathrm{NIT}^{2}$ & -0.196111 & 0.0409556 & -4.7883 & 0.0001 & \\
\hline & NIT*LAM & 0.00971073 & 0.00873201 & 1.1120 & 0.1424 & \\
\hline \multirow{6}{*}{ Sewage } & \multicolumn{6}{|c|}{$Y=a+b * X+c * X^{2}+d * Z+e^{*} X Z$} \\
\hline & Constant & 217.765 & & & & \\
\hline & LAM & 6.62948 & 1.39905 & 4.7385 & 0.0001 & \\
\hline & $\mathrm{LAM}^{2}$ & -0.0126145 & 0.00283121 & -4.4554 & 0.0002 & 0.77 \\
\hline & NIT & 0.136546 & 2.18614 & 0.0624 & 0.4755 & \\
\hline & LAM*NIT & 0.00517424 & 0.00888814 & 0.5821 & 0.2846 & \\
\hline
\end{tabular}

According to the response surface from the groundwater well irrigated sunflower (Figure 4A), the maximum PPO estimated, approximately $1207 \mathrm{~kg} \mathrm{ha}^{-1}$ was obtained with treatments D4N3 (296.64 $\mathrm{mm}$ and $75 \mathrm{~kg}$ of $\mathrm{N} \mathrm{ha}^{-1}$ ).

It was not possible to estimate the maximum point by mathematical model that adjusted to the PPO of irrigated sunflower with domestic sewage treated as the increase of PPO as a function off the nitrogen levels was linear. The highest PPO of $1.241 \mathrm{~kg} \mathrm{ha}^{-1}$ was estimated with D4N4 treatments (296.64 $\mathrm{mm}$ and $100 \mathrm{~kg}$ of $\mathrm{N} \mathrm{ha}^{-1}$ ) (Figure 4B).

Small variation of PPO for irrigated sunflower with sewage was observed as a function of the nitrogen levels. Maintaining the irrigation depth in D4 $(296.64 \mathrm{~mm})$ and reducing the dose of nitrogen from N4 (100 kg of N) to N1 (25 kg of N) would imply in reduction of only $10 \%$ in the PPO. For sunflower irrigated with groundwater well, fixing the irrigation depth in $296.64 \mathrm{~mm}$ and also by varying the dose of nitrogen from N3 (75 kg of N) to N1 (25 kg of N), the estimated reduction was approximately $25 \%$ of PPO.
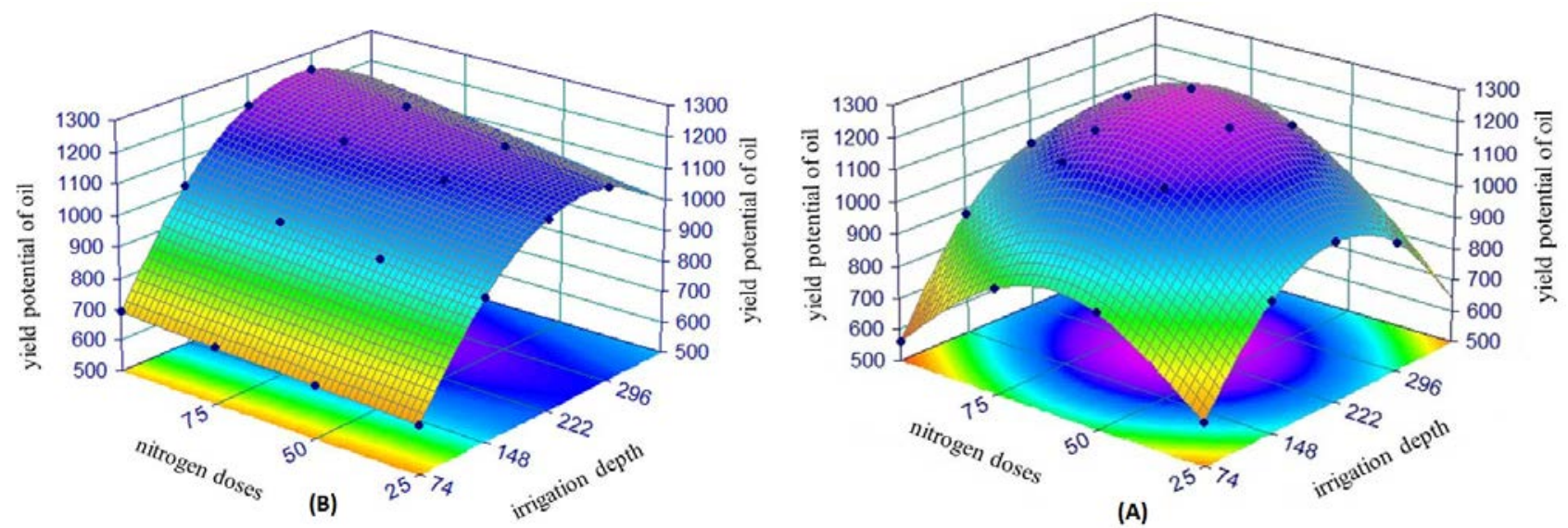

FIGURE 4. Response surface of the productive potential of oil $\left(\mathrm{kg} \mathrm{ha}^{-1}\right)$ sunflower irrigated with groundwater well table (A) and domestic treated sewage (B) according to the levels of irrigation and nitrogen doses. 


\section{CONCLUSIONS}

The domestic treated sewage can be used in sunflower irrigation. The irrigation with domestic sewage produced higher yield potential of grain and oil. The use of water from domestic treated sewage can replace up to $50 \mathrm{~kg}$ of $\mathrm{N} \mathrm{ha}^{-1}$ without affecting productivity. It is recommended the use of domestic sewage treated with irrigation depth regarding 100\% of CAE (296.64 mm) and nitrogen fertilization of $25 \mathrm{~kg} \mathrm{ha}^{-1}$ for commercial production of sunflower.

\section{REFERENCES}

AFFÉRRI, F.S.; BRITO, L.R.; SIEBENEICHLER, S.C.; PELUZIO, J.M.; NASCIMENTO, L.C. do; OLIVEIRA, T.C. de. Avaliação de cultivares de girassol, em diferentes épocas de semeadura, no sul do estado do Tocantins, safra 2005/2006. Amazônia: Ciência \& Desenvolvimento, Belém, v. 4, n. 7, 2008.

BARROS, V. das.; COSTA, R.N.T.; AGUIAR, J.V. de. Função de produção da cultura do melão para níveis de água e adubação nitrogenada no Vale do Curu - CE. Irriga, Botucatu, v. 7, n. 2, 2002.

BISCARO, G.A.; MACHADO, J.R.; TOSTA, M. da S.; MENDONÇA, V.; SORATTO, R.P.; CARVALHO, L.A. DE. Adubação nitrogenada em cobertura no girassol irrigado nas condições de Cassilândia-MS. Ciência agrotécnica, Lavras, v. 32, n. 5, 2008.

BLAMEY, F. P. C.; ZOLLINGER, R. K.;SCHNEITER, A. A. Sunflower production and culture. In: SCHNEITER, A. A. (Ed.). Sunflower technology and production. Madison: American Society of Agronomy, 1997. v.1, Cap. 5, p. 595 - 670.

CARVALHO, D. B.; PISSAIA, A. Cobertura nitrogenada em girassol sob plantio direto na palha: I rendimento de grãos e seus componentes, índice de colheita e teor de óleo. Scientia Agraria, Piracicaba, v. 3. n. 1/2, p. 41 - 45, 2002.

CHERNICHARO, C.A. de L. Pós-tratamento de efluentes de reatores. Belo Horizonte, UFMG, 2001. 544 p. Projeto PROSAB

CONAB. Companhia Nacional de Abastecimento. Brasília, 2010. Disponível em:< http://www.conab.gov.br/OlalaCMS/uploads/arquivos/10_11_16_13_07_58_apresentacaogirassol.. pdf > Acesso em: 7 de abr. 2011a

CONAB. Companhia Nacional de Abastecimento. Indicadores Agropecuários. v. 19, n. 11, 2010. Disponível em:<

http://www.conab.gov.br/OlalaCMS/uploads/arquivos/11_01_20_11_43_51_ia_nov10..pdf> Acesso em: 07 abr. 2011 (b).

FARIAS NETO, A. L.; AMABILE, R. F.; AZEVEDO, J. A. de; FONSECA, C. E. L. da; CASTIGLIONI, V. B. Avaliação de variedades de girassol nos Cerrados do Distrito Federal. Revista Ceres, Viçosa, MG, v. 273, n. 47, 2000.

GARCIA, F.C. de H.; BEZERRA, F.M.L; FREITAS, C.A.S. de. Níveis de irrigação no comportamento produtivo do mamoeiro Formosa na Chapada do Apodi, CE. Revista Ciência Agronômica, Fortaleza, v. 38, n. 2, 2007.

GRUNVALD, A.K.; CLAUDIO, C.G.P.; OLIVEIRA, A.C.B. de; ANDRADE, C.A. de B. Adaptabilidade e estabilidade de genótipos de girassol no Brasil. Central. Pesq. Agropecuária Brasileira, Brasília, v.43, n.11, 2008.

KLAR, A.E. A água no sistema solo-planta-atmosfera. 2a ed. São Paulo: Nobel, 1988.

LOBO, T.F.; GRASSI FILHO, H. Níveis de lodo de esgoto na produtividade do girassol. Revista Ciencia del Suelo e Nutricíon Vegetal, Chile, v.7, n.3, 2007. 
LUCAS FILHO, M.; PEREIRA, M.G.; SILVA, D.A. da; ANDRADE NETO, C.O. de; MELO, H.N. de S.; SILVA, G.B. da. Águas residuárias - alternativa de reúso na cultura de girassol (Helianthus annuus) In: SIMPÓSIO ÍTALO BRASILEIRO DE ENGENHARIA SANITÁRIA E AMBIENTAL, 6.,2002, Vitória. Anais...

RAMOS, J.M. Revisão de literatura: O uso da água residuária na adubação: Vantagens e limitações. Revista Científica Eletrônica de Engenharia Florestal, v. 6, n. 10, 2007. Disponível em $<$ http://www.revista.inf.br/florestal10/pages/resenhas/RESENHA_03.pdf.> Acesso em 3 ago. 2011. SANZONOWICZ, C.; AMABILE, R.F. Adubação nitrogenada do girassol, no período chuvoso e na safrinha na Região do Cerrado - Planaltina: Embrapa Cerrado, 2001. (Recomendação Técnica, 30)

SILVA, A.R.A. da; BEZERRA, F.M.L.; SOUSA, C.C.M. de; PEREIRA FILHO, J.V.; FREITAS, C.A.S. de. Desempenho de cultivares de girassol sob diferentes lâminas de irrigação no Vale do Curu, CE. Revista Ciência Agronômica, Fortaleza, v. 42, n. 1, 2011.

SILVA, M. de L.O.E.; FARIA, M.A. de; MORAIS, A.R. de; ANDRADE, G.P.; LIMA, E.M. de C. Crescimento e produtividade do girassol cultivado na entressafra com diferentes lâminas de água. Revista Brasileira de Engenharia Agrícola e Ambiental, Campina Grande, v.11, n.5, 2007.

SILVA, P.A.M.; PEREIRA, G.M.; REIS, R.P.; LIMA, L.A.; TAVEIRA, J.H. da S. Função de resposta da alface americana aos níveis de água e adubação nitrogenada. Ciência Agrotécnica, Lavras, v. 32, n. 4, 2008.

SILVA, D. J. ; QUEIROZ, A.C. Análise de alimentos: métodos químicos e biológicos. 3.ed. Viçosa: UFV, 2004. 235p.

SOUZA, N. C. de; MOTA, S. B.; BEZERRA, F. M. L.; AQUINO, B. F. de; SANTOS, A. B. dos. Produtividade da mamona irrigada com esgoto doméstico tratado. Revista Brasileira de Engenharia Agrícola e Ambiental, Campina Grande, v.14, n.5, 2010.

UNIVERSIDADE FEDERAL DO CEARÁ. Recomendações de adubação e calagem para o Estado do Ceará. Fortaleza: UFC/CCA, 1993. 248p.

ZAGONEL, J.; MUNDSTOCK, C.M. Doses e época de aplicação de nitrogênio em cobertura em duas cultivares de girassol. Pesquisa Agropecuária Brasileira, Brasília, n.26, v.9, 1991. 